\title{
128. Zur Problematik des Coeliacakompressionssyndroms
}

\author{
E.-D. Schwilden \\ Chir. Univ.-Klinik, Amsterdam (Wilhelmina Gasthuis)
}

Pathophysiological Problems of the Celiac Artery Compression Syndrome

Summary. In contrast to the well-defined clinical entity of intestinal angina the so-called "celiac artery compression syndrome" is not yet pathophysiologically explained. An analysis of the literature and the author's own clinical material is followed by a discussion of the pathophysiology of the syndrome, with the following conclusions: (1) the clinical manifestations of the celiac artery compression syndrome are essentially different from those of the well-defined clinical entity of intestinal angina; (2) the known pathophysiologic facts of visceral circulation together with clinical and experimental experience with celiac artery compression make a vascular-oschemic etiology unlikely; (3) the essential pathogenic factor seems to be the celiac ganglion situated at the site of external compression.

Key words: Artery, celiac - External compression.

Zusammenfassung. Das allgemein unter die Angina intestinalis eingeordnete Coeliacakompressionssyndrom hat bisher noch keine eindeutige pathophysiologische Erklärung gefunden. Seine Pathophysiologie wird an Hand der Literatur und 19 eigenen Patienten diskutiert mit folgenden Schlußfolgerungen: 1. Das klinische Erscheinungsbild des Kompressionssyndroms unterscheidet sich wesentlich von der Symptomatologie der Angina intestinalis. 2. Die von der Angina intestinalis her bekannte Pathophysiologie sowie die klinischen und experimentellen Erfahrungen mit der Kompression des Truncus coeliacus sprechen gegen eine vasculär-ischämische Ätiologie. 3. Eine wesentlichere pathogenetische Bedeutung scheint dem im Bereich der Kompression gelegenen Ganglion coeliacum zuzukommen.

Schliusselwörter: A. coeliaca - Externe Kompression.

\section{Der femoro-popliteale Bypass bei Verschluß aller 3 Unterschenkelarterien}

\author{
U. Rückert, J. Bräumer und L. W. Storz \\ Chirurg. Univ. Klinik Mannheim, Klinikum der Univ. Heidelberg
}

\section{Femoro-Popliteal Bypass with Occlusion of the 3 Arteries of the Lower Leg}

\begin{abstract}
Summary. The 198 reconstructions of the femoral artery performed within the last 3 years involved 18 patients with combined femoral and peripheral vascular occlusions. The bypass was connected with a segment of either the popliteal or the tibial artery. The mean period of follow-up was 8.4 months: 13 of the bypasses were patent, while 5 bypasses were occluded. Four patients required major amputation, and all of these died after amputation. The vascular operations were performed with no operative mortality. The authors feel that an isolated artery segment should be explored. The quality of the outflow tract should be demonstrated by intraoperative angiography. Only an autogenous vein graft should be implanted.
\end{abstract}

Key words: Bypass, femoral - Artery, segment, isolated. 